\title{
De la vitanda identidad entre avaricia y capitalismo y de su expresión en el cine
}

\author{
Víctor Gerardo Rivas López
}

And then this money came only to me: not to me and a rejoicing family but to my isolated self.

Charlote Brontë

\section{Introducción}

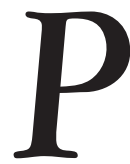

rima facie, identificar la avaricia con el capitalismo parecería remitir a un pensamiento anacrónico, a medio camino entre, por una parte, una concepción cristiana de la existencia que la filosofía moderna de Spinoza a Heidegger se ha encargado de defenestrar y, por la otra, una visión marxista de la historia como el progreso hacia la liberación final de lo humano que implicaría la superación del propio capitalismo, lo que también ha sido objeto de una crítica contundente durante los últimos decenios. Por no ir más lejos, ¿quién después del existencialismo hablaría de la proclividad del hombre como consecuencia, si es que no castigo, de una caída original? y ¿quién frente a la posmodernidad reivindicaría la libertad humana como un ideal racional y político a la luz de cuya realización habría que juzgar el proceso histórico? Es más, ¿quién condenaría el deseo por acumular riquezas sin tasa en una época en la que el único placer mayor es despilfarrarlas? Si, como lo muestra mejor que nadie Molière, la figura del avaro tuvo un sentido negativo durante el periodo de acumulación del capital, parece haberlo perdido frente a los dispendios de todo mundo.

Los términos mismos, "avaricia" y "capitalismo" no parecen, pues, tener mayor sentido ni en la realidad social ni en el discurso filosófico contemporáneos; lo que sobre todo en el caso del "capitalismo" resulta doblemente desconcertante, dado el tremendo impacto de los factores económicos en la urdimbre social durante la así llamada globalización, la cual ha coincidido con el desmantelamiento del sistema de seguridad y previsión sociales que hasta hace muy poco tuvo carta de ciudadanía en el discurso político.

Así, disertar sobre la identidad de estos dos conceptos no auguraría nada bueno si no fuese porque al margen de su respectivo marco de referencia religioso y filosófico sirven para introducirnos al análisis de un fenómeno 
que considero axial para la dinámica socio-cultural contemporánea, a saber, la inquietante desaparición de cualesquiera formas de idealidad a favor de un materialismo rampante y operativo o mediático que exige la explotación irremisible de todos los recursos naturales y humanos para proyectar una realidad que a falta de otro mejor término llamaré "global" en la que no hay estructuras que den sentido a las prácticas socio-individuales allende el intercambio de valores económicos, lo que paradójicamente reduce a cada cual a una esfera de expresión muy limitada, pese a la parafernalia mediática que ha proliferado en unos cuantos años y que nos hace sentir que tenemos acceso ilimitado a los bienes de consumo porque podemos comprar a crédito, expresar nuestro deseo sin cortapisas y conectarnos a una red en cualquier parte del mundo, triple determinación económica, libidinal y comunicativa que, en conjunto, es lo que caracteriza la fase global del capitalismo. ${ }^{1}$

Hemos pasado, según esto, de una trascendencia histórica (es decir, crítica y dialéctica) a una inmanencia global (o sea, instrumental y mediática), así como de un sistema de trabajo y seguridad institucionales a un mercado de consumo y proyección subjetiva, lo que, en una palabra, significa pasar de una idealidad de la acción socio-histórica a una materialidad de la expresión individual en la que todo tiene cabida siempre y cuando se manifieste, por una parte, como valor de cambio, como poder adquisitivo que implica una valoración en términos de provecho (en concreto, monetario) y, por la otra, como un acontecimiento instantáneo (el cliqueo de la cámara fotográfica o el del botón de cualquier dispositivo) en el que se consume el sentido específico de la realidad.

La explotación de los recursos a nuestro alcance se hermana con la del acontecer mediático en el que extrañamente nos deleitamos con la imagen de un mundo sin fronteras ni temporales ni espaciales, mas no por ello ambiguo o elusivo, ya que siempre aparece en su máxima capacidad expresiva, ${ }^{2}$ lo cual nos lleva, por extraño que parezca, al cine, que por sus características como medio artístico y de entretenimiento sirve como la matriz idónea para universalizar el materialismo que acabo de mencionar y para difundir la imagen de una riqueza inagotable que se disipa en el ocio de los personajes y en su posibilidad de siempre hacer a un lado el sufrimiento y el tedio para echar mano

${ }^{1}$ Víctor Gerardo Rivas López, "Una apología del consumismo como la forma por antonomasia de realización de lo humano en la época contemporánea", en José Ramón Fabelo Corzo y Alicia Pino Rodríguez, coords., Estética, arte y consumo. Su dinámica en la cultura contemporánea. Puebla/La Habana, BUAP/IFLH, 2011, pp. 153-179.

${ }^{2}$ Sobre la ambigüedad, véase Maurice Merleau-Ponty, Fenomenología de la percepción. París, Gallimard, 1945, pp. 235-241. 
de efectos especiales que transformarán al punto el orden de la existencia a favor, insisto, de la inmediatez material. ${ }^{3}$

Más aún, el cine, en vez de simplemente representar la realidad (como la literatura) nos la presenta en la inmediatez de la imagen, que opera de esta guisa como una auténtica teoría o visión dinámica de la existencia en la que todo está a nuestro alcance. ${ }^{4}$ Claro, puede haber conflicto y frustración para ciertos personajes (normalmente los malos de la historia) o para el espectador que se queda en Babia frente a los vuelos imaginativos o las lucubraciones metafísicas del director en turno (sobre todo si se trata de Bergman y aláteres), pero el cine compensa todo con la proyección de la imagen que nos ofrece; ${ }^{5}$ y por ello, aun sin proponérselo, tiene un profundo vínculo con la pérdida de la idealidad o trascendencia de la existencia y con el consecuente despliegue de una materialidad que concentra lo que siente y vive cualquiera en la unidad de la pantalla. ${ }^{6}$

Con todo, lo más sorprendente de esto es que semejante reducción a lo inmediato es en lo que, conforme con la concepción cristiana de la existencia, consiste el mal, cuyo más potente motor es justamente la avaricia, ya que esta última niega la trascendencia espiritual del hombre, trascendencia que, por su parte y a pesar de la inmarcesible proyección imaginativa consumista, también niega el capitalismo en cuanto modo universal y absoluto de producción en el que nada escapa a la sistemática explotación de los recursos. ${ }^{7}$ De suerte que hay una identidad entre la avaricia y el capitalismo tal, insisto, como entiendo ambos términos aquí y con independencia de su respectivo horizonte religioso, filosófico o de cualquier otra índole, identidad que se expresa de modo paradigmático en el cine, según una estructuración que merece la pena elucidar, como lo haremos a continuación.

\section{La avaricia como la génesis del mal}

En primer lugar, ¿por qué decir que la avaricia es la fuente del mal, si según la moral cristiana no es más que uno de los siete pecados capitales y no se paran-

${ }_{3}^{3}$ Jean Baudrillard, La transparence du mal. Essai sur les phénomènes extrèmes. París, Galilée, 1990, pp. 105 y ss.

${ }^{4}$ Edmond Couchot, Des images, du temps et des machines dans les arts et la communication. Arles, Jacqueline Chambon, 2007, pp. 135 y ss.

${ }^{5}$ M. Merleau-Ponty, Le cinéma et la nouvelle psichologie. Ed. de Pierre Parlant. París, Gallimard, 1996 (Folioplus/philosophie, 177), pp. 22-23.

${ }^{6}$ V. G. Rivas López, Del cine y el mal. Una ontología del presente. Puebla, BUAP/ El Errante, 2010, pp. 71 y ss.

${ }^{7}$ Carlos Marx, "Manuscritos de 1844 de economía y filosofía", en La cuestión judía 
gona con la soberbia, que perdió a Satán y al propio hombre? La respuesta a semejante pregunta tiene que ver con la concepción metafísica de raigambre platónica que fundamenta al cristianismo, según la cual este mundo es el reino del diablo,${ }^{8}$ cuyo poder se pone de manifiesto sobre todo a través del deseo desmedido, en particular del de riquezas. De ahí la constante prédica evangélica contra ellas, que se resume en la célebre afirmación de Cristo de que primero pasará un camello por el ojo de una aguja que un rico entre al reino de los cielos. ${ }^{9}$ Pues el problema no es tanto que haya ricos, sino que el hombre desee la riqueza como un fin en sí, que la convierta en el único objeto de sus afanes y que se sacie con su posesión (real o imaginaria)-olvidando con ello que solamente el cumplimiento de la voluntad de Dios puede darle la felicidad y la serenidad-, que es lo que le sucede al avaro, quien se obnubila por sus posesiones más incluso que por los deleites que le procuran y pierde el norte de la existencia. La riqueza implica un problema para quien la tiene o para quien la anhela ciegamente, y es por eso que hay que evitarla y, si ya se le tiene, deshacerse de ella cuanto antes utilizándola en beneficio de los demás. Así que la avaricia, que es el deseo de las riquezas por ellas mismas, es perniciosa en sí, como lo expresa el famoso pasaje paulino en el que se dice que "[...] la raíz de todos los males es la avaricia". ${ }^{10}$

No se trata, pues, como en el caso de la soberbia (que, como he señalado, también podría considerarse el origen del pecado), de la contumacia literalmente diabólica contra los designios divinos sino de algo muy distinto, pues mientras en el caso del soberbio hay un profundo vínculo con Dios aunque tenga un sentido por completo equívoco (que es por lo que hay en la soberbia una cierta grandeza que se refleja en los ángeles caídos), en el del avaro ese vínculo se rompe y lo único que queda es el mezquino apego a un mundo donde las cosas subyugan al hombre (cosa que también la filosofía critica).

Por otro lado, hay que señalar que el avaro nunca se ve a sí mismo como alguien malo, pues absorto en su riqueza no percibe la necesidad a su alrededor y, cuando lo hace, se justifica con alguna mínima ayuda filantrópica por la que exige el rédito del reconocimiento ajeno: da, sí, pero para recibir al mil por uno, de suerte que ni siquiera puede enmendarse, atento solamente a tener más de lo que necesita para estar bien consigo mismo, lo que nos descubre el interés que todo esto tiene para cualquier comprensión filosófica del ser del hombre, ya que al margen de las cuestiones estrictamente religiosas, mo-

(y otros escritos). Ed. de José Manuel Bermudo. Trad. de José Ma. Ripalda. Barcelona, Planeta/De Agostini, 1992, pp. 91 y ss.

${ }^{8}$ Mateo 13: 19.

${ }^{9}$ Marcos 10: 25.

${ }^{10}$ I Timoteo 6: 10. 
rales y sociales hay en juego en la condena de la avaricia, una idea de límite o sentido natural para el deseo que es lo que nos interesa destacar, pues va de la mano con la postura que, con independencia de la tradición religiosa de cuño judeocristiano a la que he aludido líneas arriba, guarda el pensamiento filosófico antiguo y, en concreto, el de Aristóteles respecto a la relación de las riquezas y el deseo. En efecto, puesto que "[...] la felicidad es [...] la actividad del alma dirigida por la virtud", ${ }^{11}$ el deseo debe por naturaleza orientarse hacia la sabiduría, por lo que todo lo que la fomente será bueno y lo que obstaculice su desarrollo será malo.

Ahora bien, respecto a la riqueza, hay que justipreciarla porque favorece la independencia del individuo virtuoso, aunque lo cierto es que casi siempre despierta un deseo excesivo, pues fomenta la búsqueda del placer y provoca un constante desequilibrio. ${ }^{12}$ Además, consiste en un bien sólo para quien la posee, cuando quien es verdaderamente virtuoso siempre busca la realización del bien común. ${ }^{13}$ Pues si el hombre es por naturaleza social, lo mejor para cada cual es contribuir al bien de todos de acuerdo con sus condiciones $y$, en ese sentido, la riqueza es un medio abstracto, a diferencia de la virtud personal, que tiene un modo de manifestarse único o específico: mientras el rico se limita a gozar de sus riquezas como cualquier otro rico, el virtuoso, en cambio, tiene virtudes siempre propias. Así que desde un punto de vista estrictamente ético, la riqueza, si bien puede desearse con mesura, siempre tiene un vínculo problemático con la virtud.

En suma, tanto para la concepción ética que Aristóteles articula como para la moral que los evangelios proclaman, la riqueza no sólo no da la felicidad que el sabio goza sino que, por el contrario, puede impedir que se alcance, máxime cuando se trata específicamente de dinero, es decir, de la materialidad de la riqueza en cuanto medio de adquisición. Pues mientras que al menos la riqueza tiene un cierto vínculo simbólico con la dimensión social de la existencia (el rico hace la mayoría de las veces ostentación de lo que tiene, pero también lo pone al servicio de los demás a través de obras o contribuciones voluntarias que le darán prestigio), el dinero es un bien abstracto, ya que con mucha facilidad provoca una pasión que a primera vista parece contraria a la avaricia, pero que es, en esencia, su contraparte: me refiero a la codicia.

El codicioso, en efecto, es el que desea el dinero por mor del dinero y sólo en segundo término para hacer algo con él, en tanto que el avaro es quien se resiste a gastarlo y trata a toda costa de ahorrar hasta el último céntimo. De manera que la diferencia entre ambos es más bien psicológica o caracteroló-

\footnotetext{
${ }^{11}$ Aristóteles, Ética a Nicómaco, 1098b. Trad. de Francisco de Paula Samaranch.

${ }^{12}$ Ibid., 1148a.

${ }^{13}$ Ibid., $1094 \mathrm{~b}$.
} 
gica pero no conceptual, pues de un modo o de otro los dos contradicen la idea del límite natural del deseo, uno porque desea como un fin absoluto lo que es solamente un medio, otro porque se niega a echar mano del medio aun a costa de provocarse con ello un daño para sí mismo. Sea como fuere, y al margen de la respectiva conformación psicológica que distingue al avaro y al ambicioso, lo que nos importa es la afirmación de un límite o finalidad natural del deseo, pues con eso nos encontramos en el seno de una visión trascendente o sustancial de la existencia que la Antigüedad reivindicó de manera mítica o dogmática o filosófica. En efecto, desde el mito hasta la reflexión aristotélica encontramos una y otra vez, en el caso de los helenos, la advertencia contra cualquier forma de deseo excesivo o desaforado que no se oriente a los objetos a los que por naturaleza debe orientarse la acción humana. ${ }^{14}$

Por otra parte, contener el deseo dentro de los lindes que le corresponden y alcanzar y mantener la ecuanimidad propia del sabio es doblemente difícil a causa de la incesante intervención de los dioses en el mundo humano y/o del carácter engañoso de la realidad social en la que el hombre se encuentra, como lo hizo ver mejor que nadie Platón al insistir en la necesidad de mantenerse alerta en todo momento contra los desafueros de la pasión. ${ }^{15} \mathrm{Y}$ si del orbe cultural helénico pasamos al judaico, la insistencia en acatar celosamente la voluntad de Yahvé y de no desear lo que no le pertenece a uno está presente desde el primer instante. ${ }^{16}$ Sea, pues, por la fundamentación filosófica o por el respeto religioso, la idea de que hay cosas que no deben desearse por sí mismas sale una y otra vez a la luz en la Antigüedad. Y entre esas cosas están en primerísimo lugar las riquezas y particularmente el dinero que, como acabamos de decir, representa un valor de cambio totalmente indeterminado y ajeno a la naturaleza social y sustancial del hombre.

A hora bien, si de este marco de referencia antiguo o metafísico pasamos a la sociedad capitalista que en nuestros días se define como materialista y global, lo primero que notaremos será la drástica sustitución de la ley natural por una ley racional (que en el mejor de los casos, como lo ilustra el pensamiento de Kant, sólo puede apelar a un cuestionable sentimiento de deber) o, en el extremo contrario, por la mera lógica de los hechos, la ley de la selva que Hobbes fue el primero en analizar filosóficamente ${ }^{17}$ y que hay que aceptar, ya que no hay más remedio; lógica que, por otro lado, se impone con doble fuerza ante la desaparición de cualquier forma de trascendencia, incluyendo la de la

${ }^{14}$ Martha C. Nussbaum, The Frailty of Goodness. Luck and Ethics in Greek Tragedy and Philosophy. Cambridge, Universidad de Cambridge, 1986, pp. 5 y ss.

${ }^{15}$ Platón, Fedro, 256a.

${ }^{16}$ Génesis 3: 17.

${ }^{17}$ Thomas Hobbes, Leviatán o la materia, forma y poder de una república eclesiástica y civil. Ed. de C. B. Macpherson. Londres, Penguin, 1968, pp. 185-188. 
propia razón, que la época contemporánea ha reducido a un devenir histórico cada vez más violento. ${ }^{18} \mathrm{~A}$ la luz de esto, la célebre tercera formulación del imperativo categórico, "obra de tal manera que uses la humanidad, sea en tu propia persona o en la persona de cualquier otro, siempre y al mismo tiempo como un fin y nunca meramente como un medio", ${ }^{19}$ muestra al unísono que no hay ningún fin natural para el deseo fuera de la determinación racional o trascendental y que es muy endeble la obligación de constreñir el impulso desiderativo a los términos de una experiencia universal y necesaria donde los derechos de cada cual valen por los de cualquier otro. ${ }^{20}$

En vez de identificarse con una comunidad de modo esencial, como lo hace el ciudadano arquetípico en el que pensó Aristóteles, o de obedecer los designios divinos hasta la oblación de sí, como lo exige la moral cristiana, el sujeto global debería definir su relación consigo mismo y con los demás sin tomar en cuenta otra ley que la que la razón le dicta, a cuya obediencia lo empuja el sentimiento de deber que, sin embargo, es incapaz de hacer frente a la plétora material del mundo que pasa por encima de las restricciones formales de aquél. ${ }^{21}$ Pues allende las condiciones a priori de la experiencia práctica que solamente se cumplen en las reflexiones filosóficas, no es un principio imperativo el que determina al sujeto que se ve libre de la ley natural sino el empuje del deseo, y justamente el de gozar ilimitadamente, lo cual nos lleva a una visión de la existencia en la que todo se articula como valor de cambio o materialidad pura al servicio del deseo, que es justamente lo que vivimos hoy en día en las distintas esferas de la realidad sociocultural como lo vio con admirable clarividencia Marx, quien tuvo desde un principio claro que la cuestión trascendía con creces el plano de la estructura de producción y abarcaba el dinamismo global de la superestructura valorativa de la existencia.

De esta suerte, "todo lo que es sólido se desvanece en el aire, se profana todo lo que es sacro y al hombre se le obliga a la postre a enfrentar con sobriedad sus condiciones reales de vida y sus relaciones con sus congéneres" ${ }^{22}$ por lo que hay que comprender de qué manera el capitalismo como un sistema de producción y explotación global devasta la idealidad de la existencia tanto en el sentido literal como en el peyorativo del término "idealidad", pues no

${ }^{18}$ Confróntese al respecto el diálogo de Foucault y Deleuze con el que se inicia $U n$ diálogo sobre el poder y otras conversaciones. Ed. y trad. de Miguel Morey. Madrid, Alianza, 1981 (El libro de bolsillo, 816), pp. 7-19.

${ }^{19}$ Immanuel Kant, Groundwork of the Metaphysics of Morals. Ed. y trad. de Mary Gregor. Cambridge, Universidad de Cambridge, 1997, p. 38.

${ }^{20}$ Ibid., p. 46.

${ }^{21}$ Idem.

${ }^{22}$ Karl Marx y Friedrich Engels, The Communist Manifesto and other Writings. Ed. de Martin Puchner. Trad. inglesa de Samuel Moore. Nueva York, Barnes \& Noble, 2005 (Classics), p. 10. 
es nada más que las anacrónicas idealizaciones metafísicas del hombre se desvanezcan y entonces podamos entablar una relación crítica con el supuesto sentido de la existencia, sino que también se desvanece el fundamento mismo para esa relación, lo cual, por extraño que parezca, nos lanza a una época no de auténtica transvaloración de todos los valores, como hubiesen pensado Nietzsche y el propio Marx, sino a una época en que la valoración pende de una materialización absoluta de lo humano, del indómito deseo que sin haber pasado por la criba de la historia (como lo exigen tanto el proyecto marxista revolucionario como el proyecto genealógico nietzscheano) se yergue sin tomar en cuenta la finitud de la existencia y sólo obedece a las necesidades o más bien carencias psicológicas o fisiológicas de cada cual. Pues en vez de conducir a la satisfacción inmediata y absoluta del deseo como su término final, la historia saca a la luz la compleja relación del mismo con la dialéctica ideal del valor y de la producción, los dos extremos entre los que se precipita la fuerza desiderativa. Por ello, contra la inquietud que llevó a Dostoievski a pensar que si Dios no existe todo está permitido, ${ }^{23}$ habría que argüir que, con Dios o sin Él, la existencia posee una idealidad crítica de suyo que Marx llamó dialéctica y Nietzsche trágica, y que la época contemporánea, empero, ha reducido a materialidad desiderativa abstracta. ${ }^{24}$

Por supuesto, huelga decir que esta materialidad no tiene nada que ver con el materialismo filosófico que el marxismo reivindicó sino, por el contrario, con una forma de experimentar la realidad como imagen o espectáculo, ${ }^{25}$ lo cual, por volver al núcleo de nuestra disertación, conduce sin muchos ambages a una insólita universalización de la avaricia y/o de la codicia de acuerdo con la cual ya no es menester desear sin tasa el dinero y mucho menos la riqueza en su sentido simbólico simple y llanamente porque todo se determina a través de la siniestra simbiosis de una materialidad abstracta y acrítica con un deseo ciego y brutal que ya ni siquiera requiere un cuerpo natural para devorarnos, lo cual permite superar la aparente contradicción entre la avaricia y el despilfarro que parece negarla cuando, en el fondo, la lleva a su máxima expresión, pues pone en primer término un flujo monetario cuya realidad es simultáneamente virtual o mediática y material o desiderativa, y eso hace que el avaro pase por

${ }^{23}$ Fiódor Dostoievski, "Los hermanos Karamasovi", en Obras completas. Trad. de Rafael Cansinos Ansséns. Madrid, Aguilar, 1991, vol. III, p. 1322.

${ }^{24}$ Contra lo que suele pensarse, hay en el pensamiento de Nietzsche una crítica muy consistente contra la sensualidad que se expresa sin la mediación del arte y la propia historia. $C f$., por ejemplo, Más allá del bien y del mal. Preludio de una filosofía del futuro. Trad. de Andrés Sánchez Pascual. Madrid, Alianza, 1972 (El libro de bolsillo, 406), aforismos 120, 194, 213, etcétera.

${ }^{25}$ Guy Debord, La société du spectacle. París, Gallimard, 1992 (Folio, 2788), pp. 15 y ss. 
un sujeto liberal que se mueve sin problemas en una dimensión donde no hay determinaciones morales.

Así, la avaricia deja de ser la raíz del mal en la medida en que el mal pierde sentido como valor negativo frente al avasallamiento del deseo pseudo-mítico que se disfraza con los ribetes de la liberación, de suerte que ya no hay que ocultar el dinero en los recovecos de algún sótano o privarse de las más elementales comodidades como Harpagón y todas sus rencarnaciones, al revés, hay que derrochar siempre y cuando el dispendio sirva para mantener la vertiginosa excitación que, merced al carácter puramente mediático del proceso, carece de la potencia indispensable para transfigurar al sujeto, pues lo exime de todo esfuerzo de formalización de la experiencia, por lo que aquél se deja llevar hacia fines bien determinados sin preocuparse de lo que acontece a su alrededor. La avaricia fija entonces dentro de lindes absolutos y al unísono especulares la efusión desiderativa sin necesidad de un ordenamiento moral crítico, y con ello fomenta la pérdida de la identidad común y de la capacidad de análisis y resistencia, pues la socialización ahora se realiza a través de los medios de entretenimiento que a su vez son modos de mantener al sujeto dentro de una realidad literalmente espectacular donde está de sobra la fuerza estructural de la razón que es el fundamento de cualquier ideal. Y con ello pasamos al siguiente punto de nuestro análisis.

\section{De la expresión cinematográfica de la avaricia}

Para retomar lo que he dicho en la introducción, creo que hay una razón axial por la que el cine ofrece a la avaricia un medio de difusión y expresión cuya efectividad ni el teatro ni la literatura podrían igualar, y es que el cine, a diferencia de estas dos últimas artes, prescinde de la reflexión que por fuerza exigen el lenguaje oral o el escrito para hacerse comprender y muestra la realidad en el plano de la inmediatez visual, pero también dramática o subjetiva de nuestra época. ${ }^{26}$ Dinamismo infinito, el cine nos hace experimentar (más que meramente ver) la estructura materialista que hemos analizado en la sección precedente, y por ello cuando trata el tema de la avaricia lo hace con una efectividad que ni un dramaturgo como Molière ni un novelista como Dickens (creadores de sendos prototipos del avaro) hubiesen alcanzado en virtud de la naturaleza de su respectivo medio artístico pero también de la diferencia ideal e histórica de la relación de la ficción con la existencia que el teatro y la

${ }^{26}$ V. G. Rivas López, "The only star in a nihilist heaven: a reflection on the problematic identity of history, art and cinema", en Patricia Trutty-Coohill, ed., Art Inspiring Transmutations of Life. Dordrecht, Springer, 2010, pp. 305-322. 
novela sostienen de principio a fin y que el cine pone en entredicho por su condición estética y, sobre todo, por la determinación materialista de la que es producto y simultáneamente adalid. ${ }^{27}$ Respecto a lo primero, recordemos que el cine no nos muestra al personaje a través del texto sino a través de la caracterización del actor; ${ }^{28}$ en cuanto a lo segundo, hay que considerar que al terminar la cinta, el actor recupera su identidad y vuelve al vértigo del mundo en el que cada uno de nosotros brega. ${ }^{29}$ Es decir, el actor encarna un tipo humano como cualquier otro de nosotros, no un arquetipo que trasciende el momento histórico, de suerte que la inmanencia sociocultural se prolonga a través de la cinta y hace ver que el presente es el molde de cualquier época.

Además, cuando, por ejemplo, un director nos pone al inicio de la película que ésta se basa en hechos reales, apenas podemos dudar y corremos a internet a buscar las bases documentales del asunto para descubrir que el tal anuncio es o una broma o un ardid publicitario que va de la mano con la avidez de novedades que caracteriza al hombre contemporáneo. ${ }^{30}$ Más aún, dicha avidez se despierta al doble al tratarse de la avaricia porque ante la incesante prédica del bienestar, del consumismo y del flujo de recursos que ninguna crisis puede agotar, la avaricia no pareciera tener mayor sentido en la vivencia socio-individual: que escatime quien no tenga o quien, teniendo, no quiera gastar, pero el hombre contemporáneo no sólo tiene sino que quiere gastar a manos llenas para colmar el tiempo con todos los artificios, dispositivos y experiencias habidos y por haber, a la luz de los cuales es inimaginable que haya alguien en verdad miserable simplemente porque, ¿quién no querría gastar sin fijarse en el precio cuando hay miríadas de objetos alrededor y la vida no alcanza para disfrutarlos y desecharlos?

Frente a la producción frenética de hoy en día, la mezquindad pierde sentido por completo. Mas la realidad nos dice justamente lo contrario: el derroche en algún momento arrasa con todos los ideales y nos pone frente a frente con la avaricia en toda su crudeza, que es lo que sucede en una película que considero fundamental para comprender el alcance y sentido del fenómeno

${ }^{27}$ Determinación que, empero, no mella la calidad estética del mismo ni su condición fenomenológica como trasunto de la realidad humana. $C f$. André Bazin, "Ontologie de l'image photographique", en Qu'est-ce que le cinéma? París, Cerf-Corlet, 2007 (7Art, 60), pp. 9-17.

${ }_{28}$ Mikel Dufrenne, Phénomenologie de l'expérience esthétique. París, PUF, 1953, pp. 61-62.

${ }^{29}$ Fredric Jameson, "On magic realism in film", en Signatures of the Visible. Nueva York, Routledge, 2007, pp. 176 y ss.

${ }^{30}$ Huelga decir que esta característica no sólo atañe a lo humano en nuestra época sino en cualquiera, aunque es en el presente que su comprensión ontológica sale a la luz. $C f$. Martín Heidegger, El ser y el tiempo. 2a. ed. Trad. de José Gaos. México, FCE, 1971 , pp. 189 y ss. 
para nosotros: me refiero a Fargo, secuestro voluntario (1996), que comienza con el anuncio de que lo que trata la obra son hechos reales, cosa que, como he mencionado unas líneas arriba, no pasa de ser un guiño de los hermanos Cohen hacia esa capacidad que el cine tiene de poner la existencia a la vista y derribar la barrera de la verosimilitud. ${ }^{31}$

Lo terrible, sin embargo, es que resulte creíble el falso anuncio y que sólo mucho tiempo después se entere uno de que no era cierto, pues esa verosimilitud confirma que los horrores que vemos en la pantalla son moneda de uso corriente en nuestra época. Y no porque resulta tan aberrante que la avaricia orille a los peores crímenes a un pobre diablo como el protagonista, sino porque eso se refleja de un modo o de otro en casi todos los personajes de la cinta. En otros términos, esta última nos hace ver sin ninguna duda que la avaricia y la codicia, que, como hemos visto, es su contraparte y sólo varía en su estructuración psicológica, son los auténticos motores de la vida social contemporánea y que los que se salvan de ellas son tan abyectamente estultos que no tienen siquiera modo de entrar a la dinámica social, como lo hacen, en cambio, quienes viven pendientes del dinero y son capaces por él de pisotear la vida de los seres que supuestamente aman, lo que nos remite al materialismo rampante en el que vivimos. Más todavía, sin dinero no hay manera de tener dignidad alguna, y por ello del protagonista en adelante (con la señalada excepción de la gran antagonista, la jefa de policía que investiga el secuestro alrededor del cual se construye la anécdota) todos los personajes se dejan arrastrar sin apenas ofrecer resistencia.

El aberrante imperio de la avaricia se nos presenta en la película en un triple plano, filosófico, dramático y artístico que merece la pena analizar paso por paso. En cuanto al primero, desde el inicio experimentamos el brutal poder de la naturaleza que se materializa en los desoladores paisajes invernales de Minnesota, en el norte de Estados Unidos. La primera imagen se difumina en la atmósfera fantasmal de un paisaje nevado donde no se percibe al principio nada y en el que la única presencia es la de la melodía de chelo que punteará la acción una y otra vez con una sombría grandeza, la cual da paso a un auto que avanza remolcando a otro en medio de la ominosa albura del paisaje. Esta visión del aterrador poderío del invierno se transforma en la de la espantosa frialdad con la que el conductor del auto llega ya de noche al poblado, cuyo nombre sirve de título a la cinta, para encontrarse con dos delincuentes de poca monta a quienes les encarga que secuestren a su esposa. Es decir, la brutalidad de la naturaleza se duplica en la del mundo humano en la que lo sombrío se convierte en lo sórdido de un trato en el que la imagen

\footnotetext{
${ }^{31}$ Stanley Cavell, The World Viewed. Reflections on the Ontology of Film. Cambridge, Universidad de Harvard, 1976, pp. 80 y ss.
} 
del buen marido se derrumba ante la necesidad de pagar deudas cuantiosas cuya razón de ser nunca queda en claro, aunque conforme la película avanza el espectador intuye que se deben simplemente a la impenetrable estupidez del protagonista, quien debe haberse endeudado por querer independizarse de su suegro, un hombre ya anciano que tiene múltiples negocios y que a cada instante humilla a su yerno porque no le perdona ser un donnadie y haberse casado con su insufrible hija.

Como vemos, aquí la naturaleza no se contrapone al mundo humano sino, por extraño que parezca, al imperativo racional que debería darle un sentido ideal a las relaciones interpersonales. Y el eje de esta contraposición es justamente la codicia, la feroz necesidad del protagonista de gozar de una vida en la que sólo merece respeto quien tiene con qué pagarlo, lo cual nos lleva a la férrea ley natural que dicta que somos enemigos unos de otros simplemente porque deseamos lo mismo, es decir, tener para gastar. La codicia, así, no es sino el reflejo invertido de la avaricia con la que el suegro prefiere poner en riesgo la vida de su única hija con tal de no ceder a los extorsionadores y de no perder el dinero del rescate. Pues aunque en algún momento podría pensarse que la conducta del anciano se debe a que no quiere ceder ante los delincuentes a causa de su testarudez, lo cierto es que para él lo fundamental es la pérdida del dinero. De esta suerte, la avaricia y su contraparte se convierten en el hilo conductor de una visión de la existencia en la que únicamente cuenta el abstracto poder de lo monetario y de su reflejo social a través del éxito que es, sin embargo, una patética imagen sin sentido, como se advierte cuando antes de que se cometa el secuestro la fotografía del protagonista aparece en la pared de su oficina mientras él mismo intenta vender con engaños a un cliente un aditamento automotriz. La imagen de un trabajador responsable no corresponde en lo más mínimo con la del hombre que ha urdido un plan macabro para salir de aprietos, así como tampoco corresponde a la del esposo angustiado que se pone a ensayar cómo decirle a su suegro que han secuestrado a su esposa cuando llega al día siguiente a su casa después de salir del trabajo y descubre que el secuestro ya ha tenido lugar.

Lo más terrible es que estas imágenes sólo adquieren cuerpo, por así decirlo, cuando irrumpe en el plan del protagonista, que se suponía que iba a funcionar como un rolex, la horrenda brutalidad de uno de los secuestradores, que por una casualidad ultima sin pensarlo a tres personas que se cruzan en su camino hacia la aislada cabaña junto a un lago a donde su cómplice y él ocultarán a la víctima. La insustancialidad de la vida contemporánea (o, quizá, de la vida a secas) se desvanece cuando salen a la luz la avaricia y/o la violencia animal que socavan la idealidad por todos lados, por lo que corroboramos de qué manera la materialidad natural, económica e instintiva da un mentís a toda la trascendencia social y sentimental. Y aquí sí merece la pena hacer hincapié 
en que los únicos que se salvan de la corrosiva acción de la avaricia son esos seres que viven al margen del dinamismo social, que sólo ocupan posiciones subalternas o vegetan en una especie de nimbo doméstico sin pretensiones de ninguna índole.

En principio, son los simples, los que cumplen con su deber y nunca se preguntan nada los que más o menos permanecen a salvo de la devastación de la idealidad, mas lo anodino de su carácter impide que su presencia compense esa devastación, lo cual se echa de ver sobre todo en la figura de la jefa de policía, que como guardiana del orden actúa con un notable profesionalismo que resalta sobre la soporífera ternura que comparte con su marido, un dibujante más o menos mediocre del que espera un niño. Si la vemos a la luz de su vida personal, la jefa es una mujer común y corriente de sólida estructura moral pero sin ninguna de las características que uno supondría en el defensor arquetípico de la ley: no hay aquí heroísmo, hay una serenidad personal que basta y sobra para vivir en la medianía mas no para desentrañar el horror, como ella lo confiesa al final, cuando en el único momento de reflexión de toda la cinta se pregunta, mientras conduce en la patrulla al secuestrador más brutal, qué puede llevar a alguien a cometer todos los crímenes que el sujeto ha cometido sin tentarse el corazón. Es la simpleza, si es que no la mediocridad, la tabla de salvación para escapar de la violencia que desata la avaricia, pero para lograr asirla uno tiene que soltar literalmente la ilusión del éxito. Nada hay de heroico en la jefa de policía por más que ella cumpla con su deber, y por ello aunque a la postre hay justicia, no hay auténtico triunfo de la idealidad en el sentido filosófico del término.

Esto último nos lleva al segundo plano de la obra que quiero elucidar, el dramático, donde se hace patente con particular crudeza que la actitud del protagonista provoca la ruina de su hogar y la muerte de su esposa sin que haya el menor asomo de remordimiento, siquiera de compasión por aquélla o por el hijo de ambos, un adolescente bastante romo que tampoco despierta la menor emoción en su padre a pesar de que la crisis familiar por el fingido secuestro debería unirlos. Las únicas pasiones que vemos en el personaje son la frustración ante su irremediable fracaso, su rabia ante la incesante humillación a la que lo somete su suegro, o la codicia que precipita su vida a la catástrofe. Por su parte, la jefa de policía, si bien, como acabamos de decir, tiene principios firmes y es muy concienzuda, se desempeña en su trabajo como podría desempeñarse en cualquier otro, por lo que su pregunta final cae en el vacío para el criminal que la escucha con una expresión de insondable embrutecimiento y quizá para ella misma, cuyo desconcierto contrasta con el hecho de que está a punto de traer al mundo a un niño que deberá también acatar las dos únicas leyes que valen, la del instinto animal o la del provecho económico descarnado, que en esencia son lo mismo. 
Por ello, si vemos las cosas sin ninguna idealización, advertiremos que aunque es cierto que la avaricia y/o la codicia articulan la fábrica social y desatan la peor crueldad, no hacen mella en la conciencia individual o al menos no parecen hacerla, pues los personajes son sin excepción seres mediocres, casi idiotas, y solamente despiertan de su aletargamiento cuando la rapiña o alguna otra patología los espolea, como sucede con un antiguo compañero de clases de la jefa de policía, quien intenta seducirla torpísimamente antes de que ella descubra que es un pobre mitómano, que se inventa un pasado amoroso que es tan falso como sus posibilidades de hacerla caer en sus redes. Así que en términos de desarrollo dramático, la cinta oscila entre la brutalidad y la mezquindad pasando por una mediocridad de buen corazón sin que haya manera de salir del círculo, lo que se percibe sobre todo por medio de la repetición ad nauseam del "yeah", horrendo monosílabo que representa el alfa y el omega de la expresividad de los personajes, como cuando la jefa de policía interroga al par de jóvenes hetairas que han pasado una noche con los secuestradores y ellas son incapaces de describir a su respectivo cliente a pesar de que acaban de estar con él, lo que disimulan con una verdadera andanada de "yeahs" de la que se hace coro su interlocutora.

El "yeah" resulta, pues, en la cinta la piedra de bóveda de un lenguaje monosilábico, crudo e insignificante en el que cada objeto o valor se confunde antes de llegar a enunciarse, lo que muestra que si no hay reflexión alguna es en el fondo porque no hay sobre qué reflexionar, pues todo es intrascendente (excepto el dinero, las relaciones mercantiles y el cumplimiento de la ley que se impone a pesar del horror), de suerte que la muletilla del "yeah" sirve para colmar el vacío que sale al paso a cada instante, como cuando un oficial de policía acude al llamado del dueño de un bar cercano al lago donde los secuestradores han ocultado a su víctima. El hombre quiere comentarle al oficial lo que le ha dicho uno de los secuestradores, pero la incapacidad de comunicarse con claridad es tal que los dos personajes terminan prácticamente de espaldas uno al otro tras intercambiar una serie de frases y sin que hayan hablado en el sentido real de la palabra. Y esto también se percibe en la sola relación íntima que la obra nos presenta, la de la jefa de policía con su esposo, que pese a su solidez se mueve en el muy elemental nivel al que aspiran seres que viven sentimentalmente al día y que no se complican la vida con idealizaciones acerca del vínculo que los identifica.

Por ello, es dable considerar el impenetrable laconismo del más brutal de los dos secuestradores (quien puede pasar horas sin decir absolutamente nada), el discurso sincopado que el protagonista ensaya para darle a su suegro la noticia del secuestro y la cantilena del "yeah" como los vértices de un triángulo de incomunicación y soledad más o menos inconsciente u operativa que evita percibir lo anodino de la vida como una pesadilla tan atroz como el 
crimen que se comete justamente por una casualidad que, a diferencia de la tragedia, en la que la intervención del azar es fundamental, no se debe a un exceso de consciencia o a la contraposición entre un ideal y la realidad sino a todo lo contrario, al abandono al mero fluir del tiempo y a la satisfacción de las necesidades inmediatas, cuando no a la vesania de la avaricia que es la quintaesencia de la fase global del capitalismo, lo cual se pone de manifiesto sobre todo en la escena en que la jefa de policía tiene que gritarle dos o tres veces al secuestrador antes de que éste la escuche, pues él se halla muy ocupado en deshacerse del cadáver de su cómplice con la ayuda de una trituradora de madera: no hay manera de comunicarse porque el estrépito del aparato acalla la voz, igual que la parafernalia del mercado arrasa con cualquier forma de sentimiento personal o profundo.

Con esto pasamos, ya para concluir, al último plano de la película que quiero analizar, el artístico, donde se destaca una vez más la contraposición como estructura, en este caso entre la macabra historia que se nos refiere y el modo de contárnosla. ${ }^{32}$ Hay, en efecto, un juego magistral entre la siniestra simbiosis de la violencia, la avaricia y la estupidez común y, por el otro lado, el humor negro con el que todo se narra como si fuese mera ficción y no una historia por más que de todos modos no lo sea, puesto que aunque los hechos tienen cierta semejanza con un asesinato que se cometió unos años antes de que se rodara la película, el contenido de ésta es una invención de los Cohen.

Así, el espanto termina por ser casi un juego de imágenes donde individuos que uno puede toparse a la vuelta de la esquina cometen los peores crímenes sin tentarse el corazón, lo cual, por extraño que parezca, hace que la película resulte mucho más perturbadora, pues aquí la intensidad no depende de la acción, tan similar a cualquier delito de nota roja, sino del descubrimiento de cuán endeble resultan la integridad personal, la compenetración sentimental y los lazos familiares más fuertes frente al empuje avasallador de la avaricia y la codicia. Y esto hace que el involuntario ridículo de los personajes refleje de alguna manera la pérdida de sentido de los ideales que la sociedad preconiza aunque toda su dinámica los niegue, cosa que solamente el cine puede proyectar con la efectividad con la que lo hace y por los motivos que ya he mencionado en la introducción, a saber, porque prescinde de la mediación reflexiva que la literatura o el teatro imponen y porque nos muestra la materialidad global de la existencia tal y como cualquiera de nosotros la experimenta, es decir, en un mundo donde el dinero es el auténtico norte del deseo, donde la desoladora albura del paisaje invernal no inspira el sentimiento de lo sublime sino sugiere el mejor escondite para ocultar el rescate

${ }^{32}$ Jacques Aumont y Michel Marie, L'analyse des films. 2a. ed. París, Armand Collin, 1988 , pp. 91 y ss. 
del secuestro y donde el hogar no es el lugar del solaz y el amor sino el sitio idóneo para cometer un delito.

Esta disparidad absoluta entre la majestuosidad del paisaje y la comodidad de los espacios urbanos donde el afecto escasea se encarna en la dislocada personalidad de los personajes principales que, como ya he mencionado, sólo se dejan llevar por impulsos muy primitivos y por un afán de lucro que los envuelve justo como la nieve que rodea por doquier la acción humana. Lo cual hace que el humor negro se convierta en una herramienta efectivísima para hacernos ver no solamente las limitaciones de los personajes, sino también la fuerza que adquieren cuando se dejan llevar por la avaricia y la mezquindad. Así, el humor convierte la carga moral de la historia casi en un drama telenovelesco o en un programa de actualidades como con los que de continuo se entretienen los secuestradores, y la estructura mediática de la existencia contemporánea de la que el cine es el fundamento se universaliza y se concreta de acuerdo con el estado de ánimo del personaje en turno, sea la distracción con la que el hijo del protagonista escucha a su madre mientras ve el televisor, sea el cansancio con el que apenas lo ve la jefa de policía un momento antes de caer dormida al lado de esposo.

Por ello, la verdadera densidad de la película se halla en la complejidad de la imagen en la que se despliega la unidad ontológica de la existencia como un modo de reaccionar ante el imperio de la avaricia, sea en la desolación, en el terror o en la brutalidad, que se articulan en una melancolía sui generis que se deja sentir en las notas del chelo que de súbito nos hace recordar que pese a todo, aún puede haber un futuro para seres tan pedestres, que es por lo que en el último instante antes de dormirse y antes de que acabe la película la jefa de policía y su marido dicen con la mitigada alegría que comparten que sólo faltan dos meses para que ella dé a luz. Con lo cual el cine vuelve a mostrarse como el medio para ver con total claridad la corrosiva violencia de la avaricia y para soñar con que pasará de largo sin tocarnos a nosotros. Vale. 